10 Takaro T, Hultgren HN, Lipton MJ, Detre KM. The VA cooperative randomised study of surgery for coronary arterial occlusive disease. II. Subgroup with significant left main lesions. Circulation 1976;54,suppl 3: 107-17.

${ }^{11}$ European Coronary Surgery Study Group. Coronary artery bypass surgery in stable angina pectoris: survival at two years. Lancet 1979; : 889-93.

${ }^{12}$ Norris RM, Caughey DE, Deeming LW, Mercer CJ, Scott PJ. Coronary prognostic index for predicting survival after recovery from acute myocardial infarction. Lancet 1970;ii:485-7.

${ }^{13}$ Calvert AF, Bernstein L, Bailey IK. Physiological responses to maximal exercise in a normal Australian population-comparative values in patients with anatomically defined coronary artery disease. Aust NZ F Med 1977;7:497-506.

14 Wenger NK, Hellerstein HK, Blackburn H, Castranova SJ. Uncomplicated myocardial infarction. Current physician practice in patient management. FAMA $1973 ; 224: 511-4$.

${ }^{15}$ Norris RM, Mercer CJ. Long term prognosis following treatment in a coronary care unit. Aust NZ F Med 1973;3:31-7.

${ }^{16}$ Peel AAF, Semple T, Wang I, Lancaster WM, Dall JLG. A coronary prognostic index for grading the severity of infarction. Br Heart $\mathcal{F} 1962$; 24:745-60.

17 Helmers C. Short and long-term prognostic indices in acute myocardial infarction. Acta Med Scand [Suppl] 1973;555:1-86.

${ }^{18}$ Bigger JT, Heller CA, Wenger TL, Weld FM. Risk stratification after acute myocardial infarction. Am $\mathcal{F}$ Cardiol 1978;42:202-10.

19 Thompson PL, Fletcher EE, Katavatis V. Enzymatic indices of myocardial necrosis; influence on short and long term prognosis after myocardial infarction. Circulation 1979;59:113-9.

${ }^{20}$ Geltman EM, Ehsan AA, Campbell MK, Schechtman K, Roberts R, Sobel BE. The influence of location and extent of myocardial infarction on long-term ventricular dysrhythmia and mortality. Circulation 1979; 60:805-14.

${ }^{21}$ Davis HT, Decamilla J, Bayer LW, Moss AJ. Survivorship patterns in the post hospital phase of myocardial infarction. Circulation 1979;60:1252-8.

${ }^{22}$ Luria MH, Knocke JD, Wachs JS, Luria MA. Survival after recovery from acute myocardial infarction. Two and five year prognostic indices. Am ₹ Med $1979 ; 67: 7-14$.
${ }^{23}$ Battler A, Slutsky R, Karliner J, Froelicher V, Ashburn W, Ross J Jr. Left ventricular ejection fraction and first and third ejection fraction early after acute myocardial infarction: value for predicting mortality and morbidity. Am 7 Cardiol 1980;45:197-202.

24 Battler A, Karliner JS, Higgins CB, et al. The initial chest X-ray in acute myocardial infarction. Prediction of early and late mortality and survival. Circulation 1980;61:1004-9.

${ }^{25}$ Unstable Angina Pectoris Study Group. Unstable angina pectoris national cooperative study group to compare medical and surgical therapy. I. A report of the protocol and patient population. Am $\mathcal{f}$ Cardiol $1976 ; 37$ : 896-902.

${ }^{26}$ Rose GA. The diagnosis of ischaemic heart pain and intermittent claudication in field surveys. Bull WHO $1962 ; 27: 645-58$.

27 Jelinek VM, McDonald IG, Schweitzer P, Herman MV, Gorlin R Exercise testing in the detection of severe coronary artery disease. Aust NZ F Med 1978;8:361-5.

${ }^{28}$ Jelinek VM, McDonald IG. History, exercise test and prognosis of chest pain. Med F Aust 1980;2:25-7.

${ }^{29}$ Beard OW, Hipp HR, Robins M, Taylor JS, Ebert RV, Beran LG. Initial myocardial infarction among 503 veterans. Five-year survival. $A m \mathcal{F}$ Med $1960 ; 28: 871-83$.

${ }^{30}$ Weinblatt E, Shapiro S, Frank CW, Sager RV. Prognosis of men after first myocardial infarction; mortality and first recurrence in relation to selected parameters. Am 7 Public Health 1968;58:1329-47.

${ }^{31}$ Hunt D, Baker G, Hamer A, Pennington C, Duffield A, Sloman G. Predictors of reinfarction and sudden death in a high risk group of acute myocardial infarction survivors. Lancet 1979 ; :233-6.

32 Theroux P, Waters DD, Halphen C, Debaisieux JC, Mizgala HF Prognostic value of exercise testing soon after myocardial infarction. N Engl F Med 1979;301:341-6.

${ }^{33}$ Sami M, Kraemer H, De Busk RF. The prognostic significance of serial exercise testing after myocardial infarction. Circulation 1979;60:1238-46.

34 Borer JS, Rosing DR, Miller RH, et al. Natural history of left ventricular function during 1 year after acute myocardial infarction: comparison with clinical, electrocardiographic and biochemical determinations. Am f Cardiol 1980;46:1-12.

(Accepted 2 October 1981)

\title{
Clostridium difficile in association with sporadic diarrhoea
}

\author{
R P BRETTLE， I R POXTON，J MCC MURDOCH， R BROWN， MARIE D BYRNE，J G COLLEE
}

\begin{abstract}
A total of 154 patients admitted to an infectious diseases unit were included in a year's prospective survey of sporadic diarrhoeal disease. Stools from 19 of them yielded Clostridium difficile, generally on more than one occasion. Twelve of these patients were assessed as having a severe or moderately severe gastrointestinal illness: Cl difficile was the only pathogen isolated from 10 of them, and two had an associated salmonella infection. Seven had had a recent course of antibiotics, but five had not taken antibiotics. Faeces from seven patients with moderate or mild gastrointestinal illness yielded $\mathrm{Cl}$ difficile, and two of these patients also had an associated salmonella infection. Two patients in this group had no antibiotic history.
\end{abstract}

\footnotetext{
Department of Infectious Diseases, City Hospital, Edinburgh EH10 5SB

R P BRETTLE, MRCP, senior registrar

J MCC MURDOCH, FRCP, consultant physician

Department of Bacteriology, University Medical School, Edinburgh EH8 9AG

I R POXTON, BSC, PHD, lecturer

J G COLLEE, MD, FRCFATH, professor

R BROWN, FIMLS, chief medical laboratory scientific officer

MARIE D BYRNE, BSC, AIMLS, medical laboratory scientific officer
}

From these findings, the occurrence of $\mathrm{C}$ difficile in faeces could not be described as antibiotic-associated. Faecal $\mathrm{Cl}$ difficile cytotoxin was detected in only six patients, and generally at low levels. In such patients a more relevant pathogenic index might take account of the numbers of $\mathrm{Cl}$ difficile present and of their toxigenic potential.

\section{Introduction}

Though a pathogenic association between Clostridium difficile and pseudomembranous colitis is accepted, the role of this organism in intestinal health and disease in infants and adults is still uncertain. ${ }^{1}$ The development of better selective culture procedures has greatly facilitated the isolation of $\mathrm{Cl}$ difficile from stools. ${ }^{2}$ We have therefore conducted a prospective study to determine the range of circumstances in which $\mathrm{Cl}$ difficile may be detected and possibly implicated in sporadic cases of diarrhoea in adults admitted during one year to an infectious diseases hospital.

\section{Patients and methods}

We included in the survey all patients admitted to the infectious diseases unit during November 1979 to October 1980 who presented with diarrhoea or developed diarrhoea. During the study period there was no recognised epidemic of gastroenteritis or diarrhoeal 
disease. Diarrhoea was defined as three or more loose stools daily for one day or more. The stools of patients with diarrhoea were examined for intestinal pathogens, including Salmonella, Shigella, and Campylobacter spp and for $\mathrm{Cl}$ difficile; a sample of faeces was also referred for virological examination but not for direct electron microscopy. Patients whose stools yielded $\mathrm{Cl}$ difficile were graded retrospectively according to the severity of their illnesses on clinical grounds alone.

\section{BACTERIOLOGICAL INVESTIGATIONS}

Specimens of faeces-Samples were taken with care to avoid contamination and submitted in sterile plastic containers without transport medium. When $\mathrm{Cl}$ difficile was isolated follow-up specimens were submitted.

Microscopy-Suitable preparations of each specimen were examined by phase-contrast microscopy; a Gram smear was prepared and examined by light microscopy. Pus cells, red blood cells, and Grampositive rods with spores were noted.

Culture-Approximately $0.1 \mathrm{~g}$ or $0.1 \mathrm{ml}$ of faeces was plated on cefoxitin cycloserine fructose agar medium (CCFA) ${ }^{2}$ and incubated anaerobically in $90 \%$ hydrogen and $10 \%$ carbon dioxide for 24 hours at $37^{\circ} \mathrm{C}$. Another, similar sample was inoculated into Robertson's cooked meat broth and incubated in the same way. The CCFA plate was examined for typical colonies, and the number of $\mathrm{Cl}$ difficile in the faeces estimated semi-quantitatively: $+=$ growth in well only $\left(10^{2}-10^{3}\right.$ organisms/g faeces), $++=$ growth in well and on primary streaks $\left(10^{3}-10^{4}\right)$, and $+++=$ growth in well, primary streaks, and secondary streaks $\left(\geqslant 10^{5}\right)$. The cooked meat broth culture was plated on CCFA medium and this plate subsequently examined for $\mathrm{Cl}$ difficile and scored $t$ if positive only after enrichment. All CCFA plates were incubated for $\mathbf{4 8}$ hours before being discarded as negative. All presumptive isolates were confirmed by gas chromatography of the volatile fatty-acid products of metabolism. The acidified supernate from a 24 -hour culture in proteose peptone, yeast extract, serum, and glucose medium ${ }^{3}$ was examined on a column of $15 \%$ Supelco $\mathrm{SP} 1220,1 \% \mathrm{H}_{3} \mathrm{PO}_{4}$ on chromosorb W acid washed in a Pye Unicam model 104 gas chromatograph. A typical fatty-acid profile with pronounced peaks of acetic, N-butyric, isobutyric, $\mathrm{N}$-valeric, isovaleric, and isocaproic acids was taken as diagnostic.

Toxin assay-Toxin was assayed essentially according to Bartlett ${ }^{4}$ by observing a cytopathic effect on monolayers of human embryonic fibroblast cells. All faecal assays were performed retrospectively on specimens that had been stored at $-18^{\circ} \mathrm{C}$. Before centrifugation, solid faecal specimens were mixed with a minimum of physiological saline to give a fluid suspension; liquid specimens were used without further dilution. Neutralisation tests were performed with $\mathrm{Cl}$ sordellii antitoxin $(10 \mu$ l of a one in 25 dilution added to $90 \mu 1$ medium over the monolayer just before adding $10 \mu \mathrm{l}$ of faecal extract). The toxigenicity of fresh isolates of $\mathrm{Cl}$ difficile was estimated by assaying the supernate from five-day cultures in $3.5 \%(\mathrm{w} / \mathrm{v})$ brain-heart infusion medium supplemented with $1 \%(\mathrm{w} / \mathrm{v})$ proteose peptone (both from Oxoid).

\section{Results}

A total of 154 patients were included in the survey, 145 of whom were referred by their general practitioners and nine transferred from other hospitals. All were admitted for investigation and treatment of illnesses that either presented with or developed a diarrhoeal phase. Of these, 39 had medical or surgical conditions that might reasonably be associated with diarrhoea and not regarded as primarily infective. Of the remaining 115 patients, $27(23 \%)$ yielded enteropathogenic bacteria, $12(10 \%)$ had salmonella infections, and $15(13 \%)$ yielded campylobacters. A reovirus may have caused another one diarrhoeal episode. From four of our 115 patients a Salmonella sp and $\mathrm{Cl}$ difficile were isolated together. Eighty-seven patients had diarrhoea that might have been infective and was unexplained; from 15 of these we isolated $\mathrm{Cl}$ difficile alone.

During the survey 35 patients were admitted who did not fulfil the criteria of the study - that is, they did not produce three or more loose stools daily for one day or more. Stools from these patients were also investigated and contained no $\mathrm{Cl}$ difficile. Since other patients resident in hospital are not entirely equivalent, the 35 , like the study patients, were in the main admitted directly from the community, were regarded as matched controls.

$\mathrm{Cl}$ difficile was isolated from a total of 19 patients (group 1). Of these, 17 came from their homes and two were from other hospitals. The age range was 19 to 88 years, with a mean of 56 ; the male to female ratio was $1: 4$; two patients died; 15 of the patients presented during May to October: and one had travelled abroad recently. There was no case-to-case spread of $\mathrm{Cl}$ difficile. On only one occasion were two patients with the organism in the ward at the same time. A check on the ward area and clean bedpans during the survey yielded no $\mathrm{Cl}$ difficile.

Toxin that could be neutralised by $\mathrm{Cl}$ sordellii antitoxin was detected in the faeces of six patients in group 1 . No cytotoxin was detected in any of the specimens that were available for testing (106 tested out

Details of 19 patients from whom Cl difficile was isolated (group 1)

\begin{tabular}{|c|c|c|c|c|c|c|c|c|c|}
\hline $\begin{array}{l}\text { Case } \\
\text { No }\end{array}$ & $\begin{array}{l}\text { Age and } \\
\text { sex }\end{array}$ & $\begin{array}{l}\text { Severity } \\
\text { of illness }\end{array}$ & $\begin{array}{l}\text { Antibiotic or } \\
\text { steroid history }\end{array}$ & $\begin{array}{c}\text { Other enteric } \\
\text { pathogens isolated }\end{array}$ & $\begin{array}{l}\text { Other illnesses } \\
\text { diagnosed }\end{array}$ & $\begin{array}{c}\text { Cl difficile } \\
\text { isolated }\end{array}$ & $\begin{array}{c}\text { In-vitro } \\
\text { toxigenicity } \\
\text { titre }\end{array}$ & $\begin{array}{c}\text { Faecal } \\
\text { cytotoxin* } \\
\text { titre }\end{array}$ & $\begin{array}{c}\text { Treatment } \\
\text { and comment }\end{array}$ \\
\hline $\begin{array}{l}1 \\
2 \\
3\end{array}$ & $\begin{array}{ll}42 & F \\
69 & F \\
55 & F\end{array}$ & $\begin{array}{l}++++ \\
++++ \\
++++\end{array}$ & Co-trimoxazole $\dagger$ & & $\begin{array}{l}\text { Rheumatic heart disease } \\
\text { Diabetes, chronic } \\
\text { obstructive airways } \\
\text { disease }\end{array}$ & $\begin{array}{r}++ \\
++ \\
++\end{array}$ & $\begin{array}{r}1000 \\
100 \\
100\end{array}$ & $\begin{array}{c}64 \\
1024\end{array}$ & $\begin{array}{l}\text { Vancomycin } \\
\text { Vancomycin. Died } \\
\text { Vancomycin }\end{array}$ \\
\hline 4 & $77 \mathrm{~F}$ & +++ & & & $\begin{array}{l}\text { Ischaemic heart disease, } \\
\text { chronic obstructive } \\
\text { airways disease }\end{array}$ & +++ & 10000 & $\S$ & Vancomycin \\
\hline 5 & $88 \mathrm{~F}$ & ++++ & Ampicillin + flucloxacillin & & Ischaemic heart disease & ++ & 1000 & 16 & \multirow{4}{*}{$\begin{array}{l}\text { Vancomycin, } \\
\text { cholestyramine } \\
\text { Vancomycin } \\
\text { Vancomycin, } \\
\text { chloramphenicol }\end{array}$} \\
\hline $\begin{array}{l}6 \\
7\end{array}$ & $\begin{array}{l}40 \mathrm{M} \\
24 \mathrm{~F}\end{array}$ & $\begin{array}{l}+++t \\
++++\end{array}$ & Erythromycin & Salmonella panama $\ddagger$ & Cerebral cortical atrophy & $+\stackrel{+}{+}$ & $\S_{10}$ & $\S_{4}$ & \\
\hline 8 & $65 \mathrm{~F}$ & ++++ & $\begin{array}{l}\text { Prednisone, } \\
\text { co-trimoxazole, } \dagger \\
\text { cefuroxime } \dagger\end{array}$ & \multirow[t]{5}{*}{ Salmonella derby } & Rheumatoid arthritis & +++ & 10000 & 1024 & \\
\hline 9 & $87 \mathrm{~F}$ & +++ & Ampicillin & & \multirow{4}{*}{$\begin{array}{l}\text { Chronic obstructive } \\
\text { airways disease } \\
\text { Panhypopituitarism } \\
\text { Ischaemic heart disease, } \\
\text { hypothyroidism }\end{array}$} & + & 100000 & ND & \\
\hline 10 & $19 \mathrm{~F}$ & ++ & \multirow[t]{2}{*}{$\begin{array}{l}\text { Penicillin, cephradine, } \\
\text { prednisone }\end{array}$} & & & ++ & 10 & $\S$ & Vancomycin \\
\hline 11 & $85 \mathrm{~F}$ & +++ & & & & + & 10000 & $\S$ & Vancomycin \\
\hline 12 & $44 \mathrm{~F}$ & +++ & Doxycycline & & & + & $\S$ & $\S$ & $\begin{array}{l}\text { Cholestyramine } \\
\text { (failed), vancomycin }\end{array}$ \\
\hline $\begin{array}{l}13 \\
14\end{array}$ & $\begin{array}{l}50 \mathrm{~F} \\
84 \mathrm{~F}\end{array}$ & $\begin{array}{l}++ \\
++\end{array}$ & Ampicillin & \multirow{5}{*}{$\begin{array}{l}\text { Salmonella agona } \\
\text { Salmonella virchow } \ddagger\end{array}$} & $\begin{array}{l}\text { Colostomy, diverticulosis } \\
\text { Secondary myocardial } \\
\text { infarction }\end{array}$ & +++ & $\begin{array}{r}100000 \\
100\end{array}$ & $\S$ & Vancomycin \\
\hline 15 & $37 \mathrm{M}$ & + & Oxytetracycline & & $\begin{array}{l}\text { Hand, foot, and mouth } \\
\text { disease }\end{array}$ & + & 100 & $\S$ & \multirow{4}{*}{$\begin{array}{l}\text { Died from chronic } \\
\text { obstructive } \\
\text { airways disease }\end{array}$} \\
\hline $\begin{array}{l}16 \\
17\end{array}$ & $\begin{array}{l}79 \mathrm{M} \\
75 \mathrm{M}\end{array}$ & + & $\begin{array}{l}\text { Ampicillin, flucloxacillin } \dagger \\
\text { Chloramphenicol, } \\
\text { amoxycillin, } \dagger \\
\text { erythromycin }\end{array}$ & & $\begin{array}{l}\text { Femoral popliteal bypass } \\
\text { Chronic obstructive } \\
\text { airways disease, } \\
\text { pneumothorax }\end{array}$ & $\begin{array}{r}++ \\
+\end{array}$ & $\S^{10}$ & $\S$ & \\
\hline 18 & $19 \mathrm{~F}$ & + & \multirow[t]{2}{*}{ Flucloxacillin, lincomycin $\dagger$} & & \multirow[t]{2}{*}{$\begin{array}{l}\text { Staphylococcal skin } \\
\text { sepsis and eczema }\end{array}$} & ++ & $\S$ & $\S$ & \\
\hline 19 & $19 \mathrm{~F}$ & + & & & & ++ & $\S$ & $\S$ & \\
\hline
\end{tabular}


of a possible 135) from patients who did not have $\mathrm{Cl}$ difficile in the faeces (group 2). Twelve of the 19 patients in group 1 and 17 of the 135 in group 2 had had courses of antibiotics during the six weeks before their admission to hospital, whereas only one of the 15 patients with campylobacter diarrhoea and none of the eight with salmonella infections alone had received antibiotics during that time.

There was no appreciable difference between the two groups in age, sex, mortality, seasonal incidence, contact history, or travel abroad, and the groups were indistinguishable in terms of presentation, biochemical and haematological profiles, and clinical course. Group 2 included a wide variety of acute surgical cases (appendicitis, perforated viscus, obstructed hernia, ischaemic ileitis, and colitis) and medical conditions (diverticular disease, carcinomatosis, pneumonias, ulcerative colitis, and chronic renal failure). There was no obvious correlation with faecal excretion of $\mathrm{Cl}$ difficile in patients with diarrhoea other than recent antibiotic treatment, which was not an invariable association.

Clinical assessment-The table summarises relevant data for the 19 patients in group 1 . The patients were divided retrospectively into four groups based on the severity of their illness; duration, frequency, and persistence of diarrhoea; occurrence of blood in the stools; fever; signs and symptoms of dehydration; increased white cell counts; and low serum albumin concentrations. The four groups were clinically severe $(++++)$, moderately severe $(+++)$; moderate $(++)$, and mild $(+)$. We considered that 12 patients had appreciable enteropathy, and it was among these that the high white cell counts and low serum albumin values were recorded. The symptoms included diarrhoea, vomiting, and abdominal pain; three patients had frank blood in the stools.

Microbiological assessment-Semi-quantitative assessments of the isolation of $\mathrm{Cl}$ difficile from the 19 patients in group 1 showed many examples of poor correlation with clinical severity. This was also true of our assessments of in-vitro toxigenicity of the $\mathrm{Cl}$ difficile isolates and it was largely true of our estimations of toxin in the faeces of these patients, though with one exception (case 16) all of those with detectable faecal toxin were severely ill. Five non-cytotoxic strains of $\mathrm{Cl}$ difficile were isolated; four were associated with diarrhoea in patients from whom no other presumptive pathogen was isolated. Pathogens other than $\mathrm{Cl}$ difficile were isolated from two severely ill patients (cases 7 and 8). One of these (case 7) had an associated salmonella bacteraemia, and presented with septicaemic shock initially considered to be secondary to an Escherichia coli urinary tract infection. With the exception of these two patients, 12 had a clinically severe illness in the absence of any presumptive cause other than $\mathrm{Cl}$ difficile. Seven of the $12 \mathrm{had}$ received antibiotics within the previous six weeks, but the other five patients had not received antibiotics.

Management-Vancomycin was given to 10 of the 12 patients with clinically severe and moderately severe disease and to one patient with moderate disease. The decision to treat was clinical, though it was influenced by finding $\mathrm{Cl}$ difficile in the stools. At the time of each patient's illness we did not have the results of the faecal toxin assays; in retrospect it could be argued that several of our patients did not merit specific treatment. Cholestyramine was used only twice; it failed to improve one patient (case 12), who eventually received a course of vancomycin.

Sigmoidoscopy was performed on 11 patients (cases 1-8 and 10-12) Moderate inflammation with contact bleeding was seen in four (cases 1, 3, 7, and 8), but none had pseudomembranes or ulcers; the rest were normal. Rectal biopsy in six patients (cases 1, 3, 5, 6, 7, and 8) showed oedema with chronic or acute inflammatory infiltrates. Barium enemas were performed on two patients, and one showed severe diverticulosis.

\section{Discussion}

In a recent survey ${ }^{5}$ no $\mathrm{Cl}$ difficile was isolated from a group of 62 healthy adults, but in an earlier one up to $3 \%$ of healthy adults were found to be carrying $\mathrm{Cl}$ difficile ${ }^{6}$ Most of this work, however, was done before the introduction of the selective CCFA medium. ${ }^{2}$ Hence these surveys may have underestimated the carriage rate of $\mathrm{Cl}$ difficile if some normal adults had carried small numbers of organisms in their stools. Similarly, in our 35 controls we were unable to isolate any $\mathrm{Cl}$ difficile on CCFA. $\mathrm{Cl}$ difficile has been isolated from the urogenital tract of men and women, ${ }^{7}$ occurs commonly in the faeces of neonates, ${ }^{58}$ and has an accepted causative association with pseudomembranous colitis in adults. The organism has been associated with $6-48 \%$ of cases of antibiotic-associated diarrhoea ${ }^{9-11}$; the assumed association is based on faecal cytotoxin assays or isolations of the organism on selected media. Twelve of our 29 patients with antibiotic-associated diarrhoea yielded $\mathrm{Cl}$ difficile, but none had pseudomembranous colitis diagnosed. Mogg et $a l^{12}$ and Keighley et $\mathrm{al}^{13}$ have demonstrated the inadequacy of sigmoidoscopy and rectal biopsy and the greater reliability of faecal cytotoxin determinations in diagnosing pseudomembranous colitis.

Evidence is now appearing implicating $\mathrm{Cl}$ difficile in nonantibiotic-associated colitis, ${ }^{14-16}$ exacerbations of chronic inflammatory bowel disease,,$^{17}$ and postoperative diarrhoea. ${ }^{1013}$ The clustering of some cases suggests that cross-infection may occur. ${ }^{19}$

Falsen et $\mathrm{al}^{11}$ found that $\mathrm{Cl}$ difficile was the second commonest enteropathogenic isolate in a survey of many stool specimens submitted to a laboratory. Our hospital-based survey would have excluded many young patients with salmonella and campylobacter infections treated by general practitioners without referral to hospital. In our series $\mathrm{Cl}$ difficile was the commonest presumptive enteric pathogen. Unknown or undetected pathogens might have accounted for some of our cases of presumed infective diarrhoea. For example, the occurrence of rotaviruses and other enteropathogenic viruses in an adult population has not been adequately assessed and merits further consideration. With these provisos, $\mathrm{Cl}$ difficile seems to be associated with some cases of diarrhoea requiring admission to hospital and may be acting as a primary pathogen in a proportion of these. In common with the findings of others, ${ }^{11}{ }^{20}$ we were able to isolate an accepted infective agent from only $28(24 \%)$ of 115 patients. Our suggestion that $\mathrm{Cl}$ difficile may be an additional accepted cause of infective diarrhoea is supported by recent reports of hospital studies ${ }^{19} 21$ and animal studies. ${ }^{22} 23$

The titres of faecal cytotoxin detected in our survey (from $0-1024)$ were appreciably lower than those obtained in classic cases of pseudomembranous colitis $\left(500-400000^{24}, 1000-5000,{ }^{25}\right.$ and $\left.1000-2000^{26}\right)$. Our patients may have had illnesses at the lower end of the range of clinical severity. The $\mathrm{Cl}$ difficile isolates from five of our patients were non-cytotoxigenic, which raises the question whether non-cytotoxigenic $\mathrm{Cl}$ difficile is invariably non-pathogenic. Recent work suggests that the cytotoxin presently assayed is not the enterotoxin that causes the diarrhoea. ${ }^{27}$

When $\mathrm{Cl}$ difficile was isolated, a decision to treat was made on clinical grounds with oral vancomycin ${ }^{28}$ or with cholestyramine. ${ }^{29}$ That non-cytotoxigenic strains of $\mathrm{Cl}$ difficile might be implicated in diarrhoea led us to regard vancomycin as the first choice when specific treatment seemed to be indicated. The criteria required to implicate $\mathrm{Cl}$ difficile as an enteric pathogen are not yet clear. It may be helpful to avoid the terms toxigenic and non-toxigenic until the role of the cytotoxin and enterotoxin in relation to enterotoxicity is defined. It is important to determine whether a relation might exist between the numbers of organisms excreted, their ability to produce one or more toxic factors, the concentrations of these factors in the faeces, and the clinical condition of the patient. The epidemiology is complex ${ }^{30}$ and the enteropathogenic range of $\mathrm{Cl}$ difficile is as yet undefined. We suggest that the range of illness produced by $\mathrm{Cl}$ difficile may include sporadic infective diarrhoea and that oral vancomycin should be considered for patients whose clinical condition causes anxiety.

We thank Dr Margaret Calder and the staff of the City Hospital's bacteriology department, Dr Hamish Inglis and his colleagues at the Regional Virus Laboratory, and Professor Sir Alastair Currie and his staff at the University Department of Pathology for their help; the nursing staff of wards 16 and $16 \mathrm{~A}$ without whose help we could not have organised and collected the specimens; Mr Garry Hay for technical work; Upjohn Ltd for financial support, equipment, and help with references; the Scottish Home and Health Department (Grant No K/MRS/50/C247) for the financial support of $\mathrm{Dr} I \mathrm{R}$ 
Poxton; and Mrs J Collins for typing the manuscript. Antitoxin for neutralisation tests was obtained from Dr P D Walker, of Wellcome Research Laboratories, Beckenham.

\section{References}

' Anonymous. Antibiotic-associated colitis-the continuing saga. $\mathrm{Br} \mathrm{Med} \mathcal{J}$ $1981 ; 282: 1913-4$

${ }^{2}$ George LW, Sutter VL, Citron D, Finegold SM. Selective and differential medium for isolation of Clostridium difficile. 7 Clin Microbiol 1979 ;9: 214-9.

${ }^{3}$ Deacon AG, Duerden BI, Holbrook WP. Gas-liquid chromatography analysis of metabolic products in the identification of Bacteroidaceae of clinical interest. 7 Med Microbiol 1978;11:81-99.

4 Bartlett JG. Antibiotic-associated colitis. Clin Gastroenterol 1979;8 783-801.

${ }^{5}$ Borriello SP, Larson HE. Antibiotic and pseudomembranous colitis F Antimicrob Chemother 1981 ; , suppl A:53-62.

${ }^{6}$ George WL, Sutter VL, Finegold SM. Antibiotic agent induced diarrhoea - a bacterial disease. 7 Infect Dis 1977;136:822-8.

${ }^{7}$ Hafiz S, Morton RS, McEntegart MG, Watkins SA. Clostridium difficile in the urogenital tract of males and females. Lancet 1975;i:420-1.

${ }^{8}$ Holst E, Helin I, Mardh P-A. Recovery of Clostridium difficile from children. Scand 7 Infect Dis 1981;13:41-5.

${ }^{9}$ Bartlett JG, Moon N, Chang TW, Taylor N, Onderdonk AB. Role of Clostridium difficile in antibiotic-associated pseudomembranous colitis. Gastroenterology 1978;75:778-82.

${ }^{10}$ Keighley MRB, Burdon DW, Alexander-Williams J, et al. Diarrhoea and pseudomembranous colitis after gastrointestinal operations. Lancet 1978;ii:1165-7.

"Falsen E, Kaijser B, Nehls L, Nygren B, Svedham A. Clostridium difficile in relation to enteric bacterial pathogens. $\mathcal{F}$ Clin Microbio 1980;12:297-300.

${ }^{12}$ Mogg GAG, Keighley MRB, Burdon DW, et al. Antibiotic associated colitis-a review of 66 cases. Br $\mathcal{J}$ Surg $1979 ; 66: 738-42$.

${ }^{13}$ Keighley MRB, Arabi Y, Shinagawa N, et al. Incidence and aetiology of diarrhoea immediately after intestinal operations. Br F Surg 1978;65: 813.

14 Wald A, Mendelow H, Bartlett JG. Non-antibiotic-associated pseudo- membranous colitis due to toxin producing clostridia. Ann Intern Med 1980;92:798-9.

15 Howard JM, Sullivan SN, Troster M. Spontaneous pseudomembranous colitis. Br Med $\mathcal{7}$ 1980;281:356.

${ }^{16}$ Cundy T, Trafford JAP, Thom BT, Somerville PG. Clostridium difficile and non-antibiotic-associated colitis. Lancet 1980;ii:595.

17 LaMont JT, Trnka YM. Therapeutic implications of Clostridium difficile toxin during relapse of chronic inflammatory bowel disease. Lancet $1980 ; \mathrm{i}: 381-3$.

${ }^{18}$ Bolton RP, Sherriff RJ, Read AE. Clostridium difficile associated diarrhoea : a role in inflammatory bowel disease. Lancet 1980;i:383-4.

${ }^{19}$ Mills PR, Main ANH, Gemmell CG, Wright PA, Lee FD, Russell RI. Pseudomembranous colitis as infectious disease. Lancet $1981 ; \mathrm{i}: 552$.

20 Gillies RR. Treatment of gastro-intestinal infection: a bacteriologist's viewpoint. In: Geddes AM, Williams JD, eds. Current antibiotic therapy. Edinburgh: Churchill Livingstone, 1973:179.

${ }^{21}$ Greenfield C, Burroughs A, Szawathowski M, Bass N, Noone P, Pounder R. Is pseudomembranous colitis infectious? Lancet 1981 ; i:371-2.

22 Troshniwal R, Silva J, Fekety R. Role of environment cross infection in antibiotic-associated colitis. Clinical Research 1979;27:358A.

${ }^{23}$ Larson HE, Price AB, Borriello SP. The possible role of environmental Clostridium difficile in antibiotic-associated colitis of hamsters and man. Clinical Research 1979;27:349A.

${ }^{24}$ Kappas A, Shinagawa N, Arabi Y, et al. Diagnosis of pseudomembranous colitis. $\mathrm{Br}$ Med F 1978; :675-8.

${ }^{25}$ Larson HE, Parry JV, Price AB, Davies DR, Dolby J, Tyrrell DAJ. Undescribed toxin in pseudomembranous colitis. $\mathrm{Br} \mathrm{Med} \mathcal{F} 1977$; 1246-8.

${ }^{26}$ Pashby NL, Bolton RP, Sherriff RJ. Oral metronidazole in Clostridium difficile colitis. $\mathrm{Br} \mathrm{Med}$ f 1979;i:1605-6.

27 Burdon DW, Thompson H, Candy DCA, Kearns M, Lees D, Stephen I. Enterotoxin(s) of Clostridium difficile. Lancet 1981 ;ii :258-9.

${ }^{28}$ Burdon DW, Brown JW, Youngs DJ, et al. Antibiotic susceptibility of Clostridium difficile. $\mathcal{F}$ Antimicrob Chemother 1979;5:307-10.

${ }^{29}$ Kreutzer EW, Milligan FD. Treatment of antibiotic-associated pseudomembranous colitis with cholestyramine resin. Fohns Hopkins Med 7 1978;143:67-72.

${ }^{30} \mathrm{Kim} \mathrm{K}-\mathrm{H}$, Fekety R, Batts DH, et al. Isolation of Clostridium difficile from the environment and contacts of patients with antibiotic-associated colitis. 7 Infect Dis $1981 ; 143: 42-50$.

(Accepted 2 October 1981)

\section{SHORT REPORTS}

\section{Discharge of preterm babies from neonatal units}

Until 1978 very low-birthweight $(<1500 \mathrm{~g})$ and very preterm babies in our neonatal unit had to reach $2200 \mathrm{~g}$ before being discharged home. A controlled trial, however, showed that provided conditions at home were satisfactory and the babies were well and passsd the nadir of postnatal weight loss they could be discharged whatever their weight. ${ }^{1}$ This confirmed observations in other countries. ${ }^{2}{ }^{3}$

Such weight criteria, however, are still widely used in Britain, and we therefore report our experience.

\section{Methods and results}

From January 1978 to June 1980,103 babies of 32 weeks' gestation or less or under $1500 \mathrm{~g}$ at birth were discharged home when clinically well, passed the nadir of postnatal weight loss, and feeding satisfactorily; home conditions

Babies discharged from neonatal unit and needing admission to hospital six to nine months after delivery

\begin{tabular}{|c|c|c|}
\hline $\begin{array}{l}\text { No of } \\
\text { babies }\end{array}$ & Reason for admission & Place of admission \\
\hline $\begin{array}{l}1 \\
3 \\
1 \\
1 \\
1 \\
1 \\
2 \\
1\end{array}$ & $\begin{array}{l}\text { Bronchitis } \\
\text { Repair of inguinal hernia } \\
\text { "Top-up" transfusion for anaemia } \\
\text { Suspected non-accidental injury } \\
\text { Confirmed non-accidental injury } \\
\text { Enucleation of left eye (planned admission) } \\
\text { Investigation of congenital heart disease } \\
\text { Failure to thrive }\end{array}$ & $\begin{array}{l}\text { Children's ward } \\
\text { Neonatal unit } \\
\text { Neonatal unit } \\
\text { Neonatal unit } \\
\text { Children's ward } \\
\text { Children's ward } \\
\text { Children's ward } \\
\text { Children's ward }\end{array}$ \\
\hline
\end{tabular}

were satisfactory; and the parents wanted the baby home. After discharge they were brought regularly for follow-up. We present information up to six months beyond their corrected age of term.

Weights of the babies at discharge ranged from 1300 to $3400 \mathrm{~g}$ (mean $1830 \mathrm{~g}$ ). Average stay in hospital was five weeks (range three to seven). O the 103 babies, 88 were discharged weighing under $2200 \mathrm{~g}$ and 13 weighed $1500 \mathrm{~g}$ or less: half of these were "light for dates." Fifteen were discharged weighing $2200 \mathrm{~g}$ or more, most of these delays resulting from social problems -mother subnormal, mother in hospital, etc. Eleven babies were readmitted during follow-up (table). Only one weighed less than $2200 \mathrm{~g}$, admission being for a transfusion for anaemia. Except for one baby with failure to thrive, all had gained weight satisfactorily. None of the others would have avoided readmission had they remained in hospital till reaching $2200 \mathrm{~g}$. Readmissions were unrelated to early discharge.

\section{Comment}

Delaying discharge of small babies from neonatal units until they reach a certain weight is difficult to justify. Health, progress, and home conditions should be the essential determinants. Success depends on helping the parents form the bond with the baby which would have developed had separation not been enforced. On admission to the unit a photograph of the baby is taken for the mother to keep at her bedside. The mother is visited regularly, and as soon as she is well enough encouraged to see her baby frequently. Brothers and sisters are also encouraged to visit. For two years wearing gowns has been abandoned, with no increase in infection.

The emphasis is on a relaxed environment and helping the parents look after their baby as soon and completely as possible. Physical contact is encouraged at an early stage-cleaning the baby's mouth, changing napkins, tube feeding, etc. Generally the earlier a bond is forged the more often will the parents visit. Participation continues as the baby progresses-bathing, feeding, making up feeds, choosing clothes. Babies are encouraged to pass as quickly as possible to breast 